\title{
The reproduction of culturally marked lexical units in dramatic texts
}

\author{
N. Nechai \\ Kherson State University, Kherson, Ukraine \\ Corresponding author. E-mail: nataliiapasenchuk@gmail.com
}

Paper received 30.01.20; Accepted for publication 15.02.20.

https://doi.org/10.31174/SEND-Ph2020-217VIII65-12

\begin{abstract}
This paper focuses on presenting the linguocultural specificity of dramatic texts that is caused by peculiarities of traditions and customs of a certain nation. The present research is aimed at determining the ways of adequate reproduction of national and cultural identity of the drama. This article deals with the problem of transferring culturally marked lexical units in dramatic texts. The researcher singles out several aspects that must be taken into account by the translators who deal with dramatic texts. The findings of the current research contribute to the development of Translation Studies and can be further applied in the investigation of the reproduction of linguocultural features of the drama.
\end{abstract}

Keywords: drama, translation, culturally marked lexis, target audience.

Introduction. In the context of current globalization processes that inevitably leads to the mixing up of cultures, it is of vital importance to concentrate upon culture-specific elements concerning a certain ethnic group in order to provide effective communication and interaction between nations. One of the principal ways to distinguish culturally specific features of the national worldview is to pinpoint the linguocultural specificity of dramatic texts that belongs to a particular culture and to investigate the means of their reproduction in the target text (TT).

The relevance of the paper is determined by the definite interest of linguists to the issues of national and cultural specificity of dramatic texts, which is caused by peculiarities of historical development, beliefs, traditions, and customs of people (Aaltonen [7], Bassnett [8;9], Bidnenko [1], Schultze [19]).

Brief review of publications on the topic. A recent review of the academic research found that scholars all over the world have investigated the peculiarities of translation of drama. For instance, Brisset states that dramatic texts are adjusted to their perception and the adjustment is always socially and culturally determined [16, p. 362]. Bassnett claims that "drama translators must always take into consideration the fact that an appropriate understanding of the TT depends on interrelation with pragmatic and situational context" [8, p. 102]. Foreign and national scholars of translation also distinguish two approaches on "performability" and "readability" (Aaltonen [7]; Bidnenko [1], Matiusha [3], Nekriach [4]).Thus, Aaltonen analyzes different translation strategies for the stage-oriented text and drama intended for reading [7].

Bidnenko draws our attention to the individual views of a translator and the process of transformation of the dramatic text through foreign languages [1, 34-36]. At the same time, Matiusha concentrates on the asymmetry in Ukrainian translations of drama [3, 297-300]. Furthermore, Nekriach describes peculiarities of the two approaches to drama translation "translation for the page" and "translation for the stage" insisting on the necessity of uniting both approaches with asymmetry as a way of avoiding cultural losses [4].

In recent years, there has been a growing interest in the interdisciplinary approach to investigations of the relevance of linguocultural features in the translation of dramatic texts. Espasa pointed out that "translation is a product of interaction and the translator can foreground foreign elements or resort to a particular culture" [15, 140-141]. Brodie claims that a translator's interpretation of the ST can have a significant effect on the understanding of the cultural differences $[12,63]$. Wolf considers the translation as an act of culture-specific communication and suggests that a translator serves as the "first reader" of the source culture, and he is expected to reproduce the other in a primary stage [23, p. 128]. Meanwhile, the dramatic text is used as a teaching method for the introduction of customs and traditions of a certain culture [14, p. 162]. However, there is still a need for research on peculiarities of reproduction of drama translation with a particular focus on the cultural difficulties. The problem in translation is caused by different cultural norms in the source language and target language.

The paper aims to determine ways of adequate reproduction of the linguocultural features of the drama. The present paper sheds new light on the problems that may be encountered by translators in the process of conveying source text (ST) culture-specific elements into the TT.

With this goal in mind, we formulated the following tasks: 1) To investigate the peculiarities of translation of linguocultural features of drama; 2) To analyze different translation strategies that translators use to resolve the problems that arise when the elements of one culture should be transferred to another culture.

Methods. Complex research requires the selection of general scientific methods. This includes linguistic observation and analysis to reveal linguocultural peculiarities, special linguistic methods including linguocultural analysis, contextual method, method of text interpretation, and method of componential analysis. Special attention has been given to the comparative translation analysis, which implies the right choice of translation strategies.

Results and Discussions. The origin of drama can be traced back to ancient times. Since then, the drama has been focused on the social and cultural aspects of people's lives [20]. In our research, we support the statement put forward by Hale and Upton, who claim that drama "embodies and enacts cultural markers" in a "cultural milieu" $[11$, p. 7]. Every culture has its importance and every language reflects an individuality that differentiates one culture from another. Thus, one of the core characteristic features of drama that is significant for our study is that the latter can be culture-specific (peculiar to a certain ethnic group). The translator also deals with the issue of cultural 
representation. Although the problem of translation of drama from culture to culture is caused by the necessity to translate the source text (ST), it is, however, important to find the possible ways of cultural adaptation [13, p. 15]. A translator plays an important role in the reproduction of drama as he should consider issues of cultural transfer [16, p. 9]. Moreover, the TT should be asymmetric to its ST. This means that it should not be equal to its ST. The question arises when the translator should decide how to bring the ST to an audience whose language and culture does not coincide with that of the TT. The translator can detach himself from his translation or bring it closer to his audience [9, p. 90]. Thus, on the one hand, there is the phenomenon of foreignization which allows the translator to preserve the elements of the source culture. On the other hand, there is the domestication of the ST which involves neutralizing all culture-specific items and converting the ST into a familiar one for the target audience [21, p. 85]. A somewhat different aspect of the reproduction of the cultural issues of drama was presented by Rozhin, who claims that substituting items in the TT for specific items in the ST "simplifies the play", depriving the audience of the "true depth" [18, p. 141]. Besides, the researcher points out that it is not necessary to neutralize the ST at all.

Therefore, summarizing the mentioned ideas, we can state that the retaining and reproduction of specific cultural items is one of the most important tasks for any translator of dramatic texts. This is because drama translation is always the product of cultural exchange. The major problem is how to act following cultural issues. As a result, we see it reasonable to search for ways to attain adequacy in the translation of specific cultural items.

The following example shows how the elimination of certain cultural features of the ST causes the amplification of the cultural elements of the target audience into the TT. The noun blancmange is the English word of French origin, which is used in the meaning of a cold, sweet dessert [10]. Moreover, this gourmet dish was served to the upper class of people. The author of the ST showed that it was the object of great worth. In this particular case, the usage of the functional equivalent is necessary, as this dish is significant for the characterization of the family traditions. In Russian translation of the Russian translator Georgii Zlobin, this word was substituted by the word with more general meaning сладкое [5, p. 4]. The Ukrainian translation was variant and the culture-specific meaning of this word was also lost. The Ukrainian translator Maxym Strikha resorted to the generalization technique by using neutral word decepm [2, p. 110] that is not associated with any particular culture or country. Undoubtedly, the usage of generalization of the meaning does not reproduce the sense of an ST word. The main difficulty in translating is that it is specific to the source culture. The translation in such a way does not help to identify that the main characters of the drama are of noble origin. On the contrary, the Russian translator Andrii Zavalii used the direct equivalent of this noun бламанже [6, p. 14] that has the same meaning as in the source culture. Besides, to reproduce a culture-specific meaning of the noun blancmange in the target linguistic culture, it is better to choose the equivalent in the target language.

Having analyzed the peculiarities of reproduction of culture-specific items from the ST into the TT, it can be claimed that there are some obstacles encountered by translators. As has been observed, the translator should be aware of the peculiarities of both the source and the target culture. The translator should take the cultural background of the source language into consideration. Let's consider the following example: dandelion wine [22, p. 78]. The author of the ST uses the culture-specific item dandelion wine which has the meaning of a wine made from dandelion flowers and usually other ingredients that are produced in the home, and it is used to comfort someone in distress [24]. The Russian translator Andrii Zavalii proposed literal translation of this phrase вино из одуванчиков [6, p. 15] that is unacceptable to the target audience. In this case, it would be more appropriate to use the explanation. By resorting to this translation strategy, the target audience can get some information about the cultural concepts of the ST. In the Ukrainian translation variant, this phrase has been translated as легке вино [2, p. 112] which is easily understood by the target audience. In both the source culture and the target culture, this type of wine is served before the main course, as an aperitif.

It should be known that translators sometimes bring the ST closer to the target culture and decide to change some items and replace them which is better known in the target language society. For example, the phrase Durkee's dress ing [22, p. 25] in the source culture has the meaning of a famous sauce that was served to the aristocracy [17]. It is important to keep in mind that the target audience may have limited knowledge about the peculiarities of the source culture. The Russian translator Georgii Zlobin replaced the culture-specific item that is unknown for the target audience by neutral word гарнир [5, p. 14]. The translator also makes the source culture more acceptable for the perception of the target culture recipient. On the contrary, the other Russian translator Andrii Zavalii used the equivalent соус Дорки [6, p. 17]. The translation of the abovementioned phrase in such a way can be considered as an inadequate translation decision because of the limited background knowledge about the source culture. The Ukrainian translator Maxym Strikha replaces the culturespecific item by the word with more common meaning підлива [2, p. 117]. Although such a translation causes the loss of some of the original color of the ST, the TT is, however, more acceptable and easily understood by the target audience because it is closer to the target culture.

Additionally, against the background of analyzed problems that can be caused by the reproduction of culture-specific elements of the ST, it is efficient to provide some core aspects that must be taken into account by the translators. This involves dealing with the rendering of the above-mentioned items. The reproduction of culture-specific items from drama should include the following stages: 1) To identify the culture-specific word; 2) To perform pre-translational analysis involving the search of equivalents; 3 ) To choose the most appropriate translation strategy for reproduction linguocultural features of the ST in the TT.

Conclusion. To sum up, our study provides an insight into the peculiarities of the reproduction of the linguocultural features of the ST. According to the results of the research, the dramatic text reflects an individual worldview of a writer. He is a representative of the source culture and has his own life experience and aesthetic taste. As has been observed, the translator should be aware of the peculiarities 
of both the source and the target culture. The investigation proves that an adequate rendering of the message from the $\mathrm{ST}$ into the TT requires the consideration of the context in which the ST is represented. Thus, we singled out two major strategies that can be used in translation: 1) Preserving the foreign elements in the TT and 2) Interpreting the unknown for the target language audience culture-specific elements. This conclusion may be regarded as the prospect of further research.

\section{ЛИТЕРАТУРА}

1. Бідненко Н.П. Взаємодія культур при перекладі драматургічних творів. Матеріали сьомої міжнародної наукової конференції «Мова та культура» у 5-ти томах. Том 4. К.: Collegium. 2000. C. 34-36.

2. Вільямс Т. Скляний звіринець (пер. М.Стріхи). Кур'єр Кривбасу, 2014. № 296-297-298. С. 105-163.

3. Матюша В. Сучасні теорії перекладу драматичних творів як окремого жанру художнього перекладу. Мовні та концептуальні картини світу. Київ, 2006. № 18. Книга 1. С. 297-300.

4. Некряч Т. Переклад для сцени: перекладач як співрежисер. Мовні і концептуальні картини світу. 2013. Вип. 2. С. 241248.

5. Уильямс Т. Стеклянный зверинец (пер. Г. Злобина). М.: Гудьял-Пресс, 1999.

6. Уильямс Т. Стеклянный зверинец (пер. А. Завалий). М., 2008.

7. Aaltonen, S. (2000). Time-sharing on stage: Drama translation in theatre and society. Clevedon, England: Multilingual Matters.

8. Bassnett, S. (1991). Translating for the Theatre: the case against performability. TTR (Traduction, Terminologie, Redaction), 4(1), 99-111. https:doi.org/10.7202/037084ar

9. Bassnett, S. \& Lefevere, A. (1998). Still Trapped in the Labyrinth: Further Reflections on Translation and Theatre. In S. Bassnett \& A. Lefevere (Eds.), Constructing Cultures: Essays on Literary Translation (pp. 90-108). Clevedon: Multilingual Matters.

10. Blancmange. In Merriam-Webster online dictionary. Retrieved January 8, 2019 from https://www.merriam-webster.com/dictionary/blancmange

11. Brisset, A. The Search for a Native Language: Translation and Cultural Identity. In L. Venuti (Ed.), The Translation Studies Reader, 2000. P.343- 375. London: Routledge.

12. Brodie, G. Theatre Translation for Performance: Conflict of Interests, Conflict of Cultures. In R. Wilson \& B. Maher (Eds.), Words, Images and Performances in Translation, 2012. P. 6381. New York: Continuum.

13. Demetska, V. Translational adaptation: theoretical and methodological perspectives. The Advanced Science Journal, 2011. 1. P. $15-18$.
14. Dodson, S. J. The educational potential of drama for ESL. In G. Brauer (Ed.), Body and language: Intercultural learning through drama. 2002. P. 161-178. Westport, CT: Ablex Pub.

15. Espasa, E. Theatre and translation: Unequal exchanges in a supermarket of cultures. In A. Branchadell \& L.M. West (Eds.), Less translated languages, 58. 2005. P. 137-145. Amsterdam and Philadelphia: John Benjamins Publishing Company.

16. Hale, T. \& Upton, C.A. Introduction. In C.-A. Upton (Ed.), Moving Target: Theatre Translation and Cultural Relocation, 2014. P. 1-13. New York: Routledge.

17. Orchant, R. Durkee Sauce: What Made This Mustard And Mayo Condiment Famous? Life. Retrieved November 6, 2018 from https://www.huffpost.com/entry/durkee-saucefamous_n_2553291

18. Rozhin, K. Translating the Untranslatable Edward Redlinski's Cud Na Greenpoincie [Greenpoint Miracle] in English. In C.A. Upton (Ed.), Moving Target: Theatre Translation and Cultural Relocation, 2014. P. 139-151. New York: Routledge.

19. Schultze, B. Problems of Cultural Transfer and Cultural Identity: Personal Names and Titles in Drama Translation. In H. Kittel \& F. Armil Paul (eds.) Interculturality and the Historical Study of Literary Translations. 1991. P. 91-109. Berlin.

20. Sommerstein, A. Greek Drama and Dramatists [E-Reader Version]. Retrieved December 1, 2018 from https://www.questia.com/library/108126796/greek-dramaand-dramatists

21. Venuti, L. The translator's invisibility. London: Routledge, 1995.

22. Williams, T. The Glass Menagerie. New York: New Directions Publishing Corporation, 1999.

23. Wolf, M. Translation as a process of power: Aspects of cultural anthropology in translation. Translation as Intercultural Communication, 1997. https://doi.org/10.1075/btl.20.13wol

24. Wright, J. How to make dandelion wine. The Guardian. $\begin{array}{llll}\text { Retrieved January } & 22, & 2019 & \text { from }\end{array}$ https://www.theguardian.com/lifeandstyle/wordofmouth/2012 /apr/04/how-to-make-dandelion-wine

\section{REFERENCES}

1. Bidnenko, N. Culture and translation interaction while translating drama text. Mova i kultura: Scientific Conference Materials. K.: Collegium. 2000. P. 34-36.

2. Matiusha, V. Modern theories of translation of dramatic texts as a genre of literary translation. Movni i kontseptualni kartyny svitu, 2006. 18 (1). P. 297-300.

3. Nekriach, T. Translation for stage: translator as co-director Movni i kontseptualni kartyny svitu, 2013. 2. P. 241-248.

4. Williams, T. The Glass Menagerie (G. Zlobin, Trans.). M.: Izdvo «Gudial-Press», 1999.

5. Williams, T. The Glass Menagerie (A. Zavalii, Trans.). Retrieved November 19, 2019 from https://www.e-reading.club/

6. Williams, T. The Glass Menagerie (M. Strikha, Trans.). Kurier Kryvbasu, 2014. 296-297-298. P. 105-163. 